\title{
The Image of Scientists among Pre-Service Classroom and Child Education Teachers in Jordan
}

\author{
Eman Gheith
}

Corresponding author, Faculty of Arts, Petra University, Jordan, egheith@uop.edu.jo

\section{Nahil M Aljaberi}

Faculty of Arts, Petra University, Jordan, naljaberi@uop.edu.jo

The purpose of this study was three-fold: first, to investigate the image of scientists held by prospective teachers with respect to academic levels (1 st year and 4th year); second, to identify sources of their image; third, to identify the most influential scientists from their point of view. The sample consisted of 140 preservice classroom and child education teachers enrolled at University of Petra, Jordan. A questionnaire, the Draw-a- Scientist Test (DAST) and a number of closed- and open-ended questions were used to collect data. Results of this study showed that participants had a balanced image of scientists, offering a positive image of scientists with regard to cognitive characteristics such as intelligence and a rather negative image in affective characteristics such as religion. Results also showed that participants saw the scientist as an elderly male with unkempt hair, and working in a lab. The 4th year students demonstrated a more stereotypical image compared to 1 st year students. Findings showed that the substantial sources of their images were the following: Internet, science stories, academic texts, and teachers. The results also showed that $65.7 \%$ of participants indicated the absence of scientists in Jordan and that the most influential scientists were Einstein, Newton, Edison and Ibn- Sina.

Keywords: stereotypical image, draw-a-scientist test (DAST), pre-service teacher, child education teacher, pre-service classroom

\section{INTRODUCTION}

Teaching science aims not only to provide students with scientific knowledge but also to help them acquire attitudes and thinking skills that are necessary to solve problems and make decisions. It also aims at developing scientifically and technologically educated citizens who are able to adapt to the requirements of the present century and who appreciate science, technology and scientists (Toğrol, 2013). This requires teachers to help students understand the nature of science and how it develops as well as to make 
them aware of scientists' contributions. Understanding the nature of science and the way scientists work will help students formulate a positive image of scientists and appreciate their efforts to serve humanity. It will also help students to contribute to scientific developments in the future, participate in current scientific discussions, and implement technology in their lives. It will encourage them to choose professions that are related to science and will increase their level of achievement in science (Dikmenli, 2010; Demirbas, 2009).

For decades researchers in the field of science teaching have been interested in exploring the perceptions of scientists formed in the student's minds of different academic levels, from KG to university. It is having been realized that such conceptions can provide indicators of the extent of students' understanding of the nature of science (Schibeci, 2006), and can impact their attitudes towards science, scientists, and scientific activities (Lucas, 1983; She, 1998).

Images that students form about science and scientists have a very complex structure and are influenced by several factors such as school, books, teachers' practices, gender, extra-curricular activities, television, and science fiction novels (AğgülYalçın, 2012). Students develop personal images about science and scientists when they are exposed to a variety of learning sources in their daily activities, whether in school, or through informal learning channels. Demirbas (2009) points out that students are more influenced by outside factors such as documentaries, magazines, news broadcasts, and science fiction films. These factors may have positive or negative effects on students' understanding of the nature of science and their perceptions of science and scientists.

Several researchers indicate that diverse media often encourages the formation of stereotypical image of scientists which is biased toward gender and inconsistent. It may also depict the scientist as evil, violent, obsessive, self-centred, working alone in a lab on secret projects, socially irresponsible, mentally and morally unstable, helpless, and easily controlled (Christidou, 2011).

Many studies have been conducted regarding the factors that impact the stereotypical image of scientists; however, the influence of teachers and school science are considered important elements. Teaching science in school and the role of science teachers is significant in impacting students' perception of science and scientists. These perceptions can affect students' values and attitudes toward science and contribute to shaping their images of scientists. If students have a negative image of scientists it will prevent them from developing a positive attitude toward science and science related activities. Attitudes are considered to have a strong impact on learning and planning for future professions and leisure activities (Christidou, 2011; Toğrol, 2013).

\section{LITERATURE REVIEW}

As attitudes of teachers and students about science are related to their perception of science and scientists, scientific as well as educational institutions have been concerned for almost six decades to identify perceptions of students regarding science and scientists (She, 1998). These perceptions might have an impact on an individual's interest in learning or teaching sciences in the future (Finson, 2002). Research 
conducted by Mead and Mertraux (1957) is considered one of the first studies that attempted to describe images of scientists of high school students in the USA. Qualitative data was collected from 35,000 high school students and essay questions were used as each student was asked to write a paragraph about their perception of science and scientists. The results showed that students knew scientists stereotypically as middle-aged or older males, wearing white coats and spectacles, bearded, working in a lab, surrounded by devices and instruments, writing in a black note book, and holding dangerous secrets.

Beardslee and O'Dowd initiated a study in 1961 on the image of scientists held by university students. They used a survey to collect data. The participants included male and female students from private and public schools as well as university students at the $1^{\text {st }}$ and $4^{\text {th }}$ year levels from different socioeconomic backgrounds. The results showed insignificant differences that can be related to those variables. Participants stated that scientists have high intelligent, are hard working, and are interested in their research rather than in art, family, and friends. Many studies were conducted between the years 1957 and 1983 using different scales. The results of many of these studies showed that stereotypical images held by students were relatively stable and found in various cultures (Finson, 2002). Also, Pion and Lipsey (1981) reviewed studies that were done in the 1960s and 70s. Results indicated that teachers' and students' images of scientists were distorted and did not match what scientists do in reality.

Chambers (1983) depend on the results from previous research, developing a drawing method to depict stereotypical images of scientists found in children's drawings, taking into consideration that drawing is an effective method to identify images of scientists in the minds of students (Schibeci, 2006). He used the Draw-a-Scientist Test (DAST) and asked participants to draw an image of a scientist on a piece of paper. The sample consisted of 4,807 male and female students from $\mathrm{KG}$ to $5^{\text {th }}$ grade. The drawings were evaluated according to seven indicators including white lab coat, glasses, unkempt hair or beard, presence of research devices such lab instruments and equipment, books and file-filled cabinets, and scientific and technological terms and products. Students saw the scientist as a man who wears a lab coat and glasses and uses technological instruments, works alone in an environment equipped with chemicals as well as instruments, books, and cabinets. Chambers also studied the influence of certain factors on the images of scientists such as gender, age, socioeconomic status, and intelligence. He found that some of the female students drew pictures of female scientists. He also noticed that the stereotypical image of scientists started to appear at the $2^{\text {nd }}$ and $3^{\text {rd }}$ grade levels and was reinforced with age. However, some studies that were conducted later showed that the image held by students is shaped at an earlier stage of a student's life, namely at the age of six. Therefore, it can be said that there is a standard image of scientists in the minds of students which starts appearing in drawings by students at the KG level and reinforces between $1^{\text {st }}$ and $2^{\text {nd }}$ grade (Rawson and McCool, 2014). But strategies aimed at changing this image may be applied at a later stage (Newton and Newton, 1998).

Numerous studies have been conducted in various countries, especially the developed ones, to identify the image of scientists held by students at their different academic 
levels, or by pre-service teachers, and the influence of various factors on this image such as gender, culture, specialization, and academic level (Ackay, 2011; Newton \&Newton, 1998; McCarthy,2015; Huang et al., 2014; She, 1998; Unver, 2010; Hatzinikita, 2007; Ozel, 2012; Milford \& Tippett, 2013; Rosenthal, 1993; Karacam, 2016; Kaya et al., 2008). Moreover, studies were conducted on the effect of strategies and teaching methods in changing pre-service teachers' conceptions of science and scientists (Ucar, 2012, Mbajiorgu and Iloputaife, 2001). Numerous results showed the prevalence of the stereotypical image among pre-service teachers as the average number of indicators that were used to evaluate the students' drawings increased with the students' academic level. This means that the stereotypical image of scientists among students becomes more typical as students rise in academic level. This image becomes widespread and permanent among students at higher academic levels and among males and females as well as among diverse ethnic groups. The stereotypical image is found in different countries, whether the USA, China, Columbia, Turkey, or other countries (Finson, 2002).

\section{Previous Studies}

In light of the importance of the images of scientists held by prospective teachers (as these images are one of the most important components to scientific literacy), many researchers in various countries, especially developed countries, attempted research to reveal this image and explore the effect of variables on them such as gender, university specialization, culture, and methods of teaching, that might have a positive or negative influence. They also aimed to identify various sources that contribute to shaping this image in the minds of teachers. The following is a brief summary of these studies.

\section{Local and Arabic Studies}

When studies about the images of scientists held by prospective teachers were reviewed in Jordan and the Arab world, it was noticed that there was very little done in this field. Some Arab countries have conducted studies that dealt with images held by students and the sources that they used to formulate such images (Alzaanien, (2015); Ambusaidi et al., 20015). In Jordan and Lebanon there have been studies on scientist images in school textbook (Arar, 2000; Yacoubian et al., 2017), while in Egypt studies attempted to know the effect of scientists' biographies and the use of scientists' stories to improve the image of science and scientists in the minds of elementary students (Sharkawy,2012).

In Jordan, Arar (2000) conducted a study aimed to explore the image of science and scientists in school books from $7^{\text {th }}$ to $10^{\text {th }}$ grade and how far this image coincides with the contemporary image of science and scientists. Results showed that school science textbooks do not highlight the personal characteristics of scientists and only focus on their experimental activities in order to produce scientific knowledge. Also, books focused on scientists highlighted their ethics such as cooperation, honesty, and respect for scientific evidence. The study concluded that this image does not coincide with a contemporary view of science and scientists.

In Lebanon, Yacoubian et al., (2017) conducted a study to analyze the image of scientists in elementary school books. The results showed that scientists were shown as 
men of western origin who work alone in a lab and are distinguished by objectivity and a concern for finding facts.

Abu-Athera (2013), also conducted a study to explore the conceptions of female science teacher candidates in Saudi Arabia about the nature of science. The results showed that female students think that scientists use imagination and creativity to develop scientific knowledge and they are open-minded and unbiased.

Dikmenli (2010) also conducted a study that aimed to investigate perceptions of undergraduate biology students. He aimed to determine the image of science and scientists in the minds of these students. The results revealed that participants displayed positive and negative associations with science and scientists. It also revealed that part of these links resembled the stereotypical image that many previous studies had arrived at. His research showed that the image of a scientist is a younger male who works indoors, smiles while working, and dedicates his life to humanity. It was also noticed that the image was more positive among older students and less conventional when compared with the image held by elementary students.

Ağgül Yalçın (2012) carried out a study to explore the image of scientists in the minds of prospective teachers in relation to some variables. The results showed that participants had a stereotypical image of scientists. They were males who wore glasses, had unkempt hair, wore lab coats, were aged 30-50, worked in a lab, conducted experiments, and spent time thinking. As for knowing the best scientists, the names most commonly repeated were Einstein, Edison, and Ibn Sina, and the common resources that shaped this image were scientists' biographies, documentary films, the Internet, and books.

Huang et al., (2014) also studied the image of scientists held by pre-service teacher in China. The research showed the presence of typical images of scientists held by students who saw the scientist as distinguished by intelligence, knowledge, serious work, and responsible behavior. On the other hand, he was untidy, wore simple modest clothes, serious, slim, introverted, and not happy, while the results showed that there were a small percentage of students who held a positive view of scientists.

Unver (2010) conducted a comparative study between the $5^{\text {th }}$ grade elementary students and $4^{\text {th }}$ year university level students in regarding their perceptions of scientists. The students were asked to draw an image of the scientist. The results showed that the university students' perceptions were more stereotypical than those of the $5^{\text {th }}$ graders.

Turkmen (2015) made a comparative study of the scientists' image held by prospective teachers in Turkey, Europe, and the United States. Results showed that the images held by the prospective teachers were typical as they thought of the scientist as Caucasian, with unkempt hair, using technology. Prospective teachers thought that the sources that helped them shape their view of scientists were teachers, family, friends, and the media. The results showed that the image held by this sample was less stereotypical than the image found in previous studies. 
Milford \& Tippet (2013) conducted a study to explore the perception of prospective teachers regarding scientists. The participants were chosen from a group that was attending a course in methods of teaching high school science. Another group attended methods of teaching science to elementary students. The results showed that the teachers' drawings of the scientists reflected the typical conception of a scientist that he is a male with messy hair who wears a white coat, glasses, and works in a lab. The result showed that Students who attended the high school program offered a less stereotypical image than those who attended the elementary program.

Ucar (2012) conducted study aiming to identify pre-service teachers' conceptions of scientists and science teaching and the relation between these views and the courses that the students were attending while in university. The results showed that perception of the pre-service teachers about teaching science had changed from a view focused on the teacher to views focused on the student, but their image of scientists did not change.

In Greece, Hatzinikita (2007) conducted research aiming to identify the image of scientists in drawings by teachers who were working at different levels and were enrolled in an MA program in the College of Education. She also aimed to identify the extent of similarities between their perception of scientists and the typical image that researchers had reached using the DAST. The results showed the presence of the typical image of scientists among the participants which were influenced by gender and academic level.

Two researchers in Nigeria, Mbajiorgu and Iloputaife (2001), conduct a study to identify the impact of teaching on the images of scientists formed by pre-service teachers. The students were given a 14-week course using the constructivist teaching approach. The results showed that the course reinforced positive images about scientists.

McCarthy (2015) conducted research to identify the image of scientists held by students who were in a teacher training program in South Louisiana University and to explore the reasons behind formulating these images. The participants' drawings in the planning and evaluation program were compared with drawings of teachers in an elementary teaching methods program. The results showed some aspects of the typical image and changes in other aspects. For example, there were a larger percentage of drawings of female scientists. The study results showed that the main factors that contributed to the image of the scientist are the print and electronic media, high school classes, and university labs.

\section{Summary of previous studies}

- The stereotypical image of the scientist held by pre-service teachers is present in different cultures and is held by university students of different specializations.

- There are positive and negative perceptions held by pre-service teachers regarding the cognitive and affective characteristics of scientists.

- Some science curricula in the Arab world do not present a clear picture of scientists work and do not bring out personal traits. The picture does not coincide with the contemporary view of science and scientists.

- Studies that deal with images of scientists are very few in the Arab world. 
- Many factors contribute to shaping the image of scientists, including science books, academic texts, teachers, and various media.

- Most of the studies carried out over the past 10 years show more positive images and fewer of the stereotypical views held by university students.

- Several studies showed that the use of different teaching methods by university instructors may improve perceptions of scientists such as those that focus on students and provide student with inquiry activities in science courses.

\section{Aim and Significance of the Study}

Many studies have been carried out worldwide on teachers' and students' conceptions of scientists. The results showed that teachers and students have a stereotypical image of scientists and what they do. Also, many recent studies indicated that perceptions of scientists have become less stereotypical than in previous years. This image is influenced by many factors such as the audio and visual media, academic texts, science fiction novels, methods of teaching science, extracurricular activities, instructor's practices, personality, gender, and grade level.

There is no doubt that the presence of stereotypical negative images of scientists by teachers impacts their attitude toward science which may influence their teaching practices. This perception influences in turn their students' attitudes toward science and contributes to shaping images that they develop about scientists and their activities (Toğrol, 2013; Christidou, 2011). Since it is important that the teacher has positive image of scientists that can be conveyed to his students when he practices teaching in the future, The researchers attempted to identify the image of scientists in the minds of pre-service teachers of kindergarten and first three grades, especially that many studies indicated that images of science and scientists are formed by students at the pre-school level and take shape between grades 1 and 2 (Rawson \& McCool (2014). The findings of this study are particularly important because there are very few studies in Jordan that have dealt with perceptions of scientists, whether by students or teachers.

\section{Study Questions}

The study attempted to answer the following questions:

Question One: What is the image of scientists held by $1^{\text {st }}$ and $4^{\text {th }}$ year prospective teachers in the field of child education and classroom teacher at the University of Petra? Does it change in relation to the students' academic level?

Question Two: What are the substantial sources that contribute to shaping the image of prospective teachers?

Question Three: How much do prospective teachers know about scientists in Jordan?

Question four: Who are the most influential scientists around the world from their point of view?

\section{METHOD}

\section{Study Tools}

The tool used in this study consists of 5 parts. Part one asks for general information about the student such as gender, academic level, and specialization (classroom teacher 
or child education). Part Two is a scale that has 12 characteristics of scientists with responses organized on a 5-point Likert scale in which 5 indicates the scientist's positive characteristics and 1 the negative characteristics. The number 3 indicates that the student is uncertain about the scientist's characteristics. A scale developed by Song and Kim (1999) has been used. These features include caution, intelligence, dedication, creativity, open-mindedness, aesthetic appreciation, pleasantness, humanity, responsibility, religiousness, empathy, and working for peace. Part Three consists of a DAST (Draw-A-Scientist-Test) that include asking students to draw a picture of the scientist indicating gender, age (less than 40, over 40), and writing three things the scientist usually performs, as well as the place the scientist works. The drawing has been analysed according to the following indicators: gender, age, lab coat, glasses, beard, hair, learning devices, research devices, scientific terms, working in the lab, and presence in closed areas. Part Four presents a question with ten choices to pinpoint the sources that influence the conception that the student has formed about scientists. These choices are school books, scientists' biographies, teachers, university instructors, films, Internet, cartoons, animations, magazines, family, scientific museums, and other sources. The student assigns the most important three sources that contributed in formulating image of the scientist. These sources were chosen after reviewing various studies such as Aggul Yalcin (2012), Turkmen (2015), and McCarthy (2015). Part Five is an open-ended question in which the student is asked to write the name of a Jordanian scientist, the reason for his/her choice, as well as the name of an international scientist who is considered to be the best and the reason for his choice.

The Kronbach alpha coefficient was calculated for the scale that included the characteristics of the scientists. The coefficient of correlation was 0.74 . To reach stability in the analysis of the scientist's image a number of students' drawings were chosen and were analysed by an external evaluator. The two analysis results were closely matching.

\section{Population of the Study}

The population included all science education students specializing in classroom teacher and child education in the Faculty of Arts and Sciences in University of Petra, 20172018. A sample of 140 male and female students was selected from the $1^{\text {st }}$ and $4^{\text {th }}$ year levels. Most of them were females (134 females, 6 males). There were (64) $1^{\text {st }}$ year students and (76) $4^{\text {th }}$ year students.

\section{Limitations of the Study}

1. As many researchers have indicated (Fung, 2002; Medina-Jerez et al., 2010), the DAST tool gives reliable results but does not provide reasons for the forming the image and reinforcing it when moving from one academic level to a higher level.

2. The size of the sample is limited and increasing the number of participants would give a clearer picture of the images of scientists formed by prospective teachers.

3. The study is limited to classroom teacher and child education students and not applied to university students of different specializations. 


\section{FINDINGS}

To answer the first question "What is the image of scientists held by $1^{\text {st }}$ and $4^{\text {th }}$ year prospective teachers in the field of child education and classroom teacher at the University of Petra? Does it change in relation to the students' academic level?" the following calculations were made.

First: The mean and standard deviations were calculated for the answers provided by $1^{\text {st }}$ and $4^{\text {th }}$ sample students in the first part of the questionnaire which is related to characteristics of scientists. Table 1 shows the mean and standard deviations of the teacher students' scores with regard to scientists' characteristics on a 1-5 scale for each trait. The number 5 refers to approval of the scientists' positive characteristics and the number 1 refers to agreement with negative characteristics, while the number 3 indicates an absence of knowledge of positive or negative characteristics.

Table 1

The Mean and Standard Deviations of the Teacher Students' Scores with Regard to Scientists' Characteristics

\begin{tabular}{|c|c|c|c|c|c|c|c|}
\hline No. & Scientists' characteristics & $\begin{array}{l}\text { Academic } \\
\text { level }\end{array}$ & $\begin{array}{l}\text { No. of } \\
\text { students }\end{array}$ & Avg. & $\begin{array}{l}\text { Std. } \\
\text { Dev. }\end{array}$ & Avg. & $\begin{array}{l}\text { Std. } \\
\text { Dev. }\end{array}$ \\
\hline \multirow[b]{2}{*}{1} & \multirow[b]{2}{*}{ cautious/reckless } & $1^{\text {st }}$ year & 64 & 3.83 & 1.20 & \multirow{2}{*}{3.96} & \multirow{2}{*}{1.17} \\
\hline & & $4^{\text {th }}$ year & 76 & 4.07 & 1.13 & & \\
\hline \multirow{2}{*}{2} & \multirow{2}{*}{ intelligent/ignorant } & $1^{\text {st }}$ year & 64 & 4.53 & 0.82 & \multirow{2}{*}{4.56} & \multirow{2}{*}{0.78} \\
\hline & & $4^{\text {th }}$ year & 76 & 4.59 & 0.75 & & \\
\hline \multirow[b]{2}{*}{3} & \multirow{2}{*}{ hard worker/lazy } & $1^{\text {st }}$ year & 64 & 4.30 & 1.03 & \multirow{2}{*}{4.47} & \multirow{2}{*}{0.91} \\
\hline & & $4^{\text {th }}$ year & 76 & 4.62 & 0.77 & & \\
\hline \multirow[b]{2}{*}{4} & \multirow{2}{*}{ creative/dull } & $1^{\text {st }}$ year & 64 & 4.61 & 0.79 & \multirow{2}{*}{4.50} & \multirow{2}{*}{0.88} \\
\hline & & $4^{\text {th }}$ year & 76 & 4.41 & 0.94 & & \\
\hline \multirow{2}{*}{5} & \multirow{2}{*}{ open-minded/fixed minded } & $1^{\text {st }}$ year & 64 & 4.14 & 0.92 & \multirow{2}{*}{4.08} & \multirow{2}{*}{1.02} \\
\hline & & $4^{\text {th }}$ year & 76 & 4.02 & 1.09 & & \\
\hline \multirow[b]{2}{*}{6} & \multirow{2}{*}{ interesting/boring } & $1^{\text {st }}$ year & 64 & 3.05 & 1.10 & \multirow[b]{2}{*}{3.02} & \multirow{2}{*}{1.15} \\
\hline & & $4^{\text {th }}$ year & 76 & 3.00 & 1.20 & & \\
\hline \multirow{2}{*}{7} & \multirow{2}{*}{$\begin{array}{l}\text { appreciates } \\
\text { beauty/unappreciative }\end{array}$} & $1^{\text {st }}$ year & 64 & 3.25 & 1.17 & \multirow{2}{*}{3.09} & \multirow{2}{*}{1.18} \\
\hline & & $4^{\text {th }}$ year & 76 & 2.96 & 1.18 & & \\
\hline \multirow{2}{*}{8} & \multirow{2}{*}{ humane/inhumane } & $1^{\text {st }}$ year & 64 & 3.92 & 1.04 & \multirow{2}{*}{3.89} & \multirow{2}{*}{1.08} \\
\hline & & $4^{\text {th }}$ year & 76 & 3.86 & 1.11 & & \\
\hline & & $1^{\text {st }}$ year & 64 & 4.17 & 1.08 & & \\
\hline 9 & responsible/irresponsible & $4^{\text {th }}$ year & 76 & 4.08 & 1.19 & 4.12 & 1.13 \\
\hline & & $1^{\text {st }}$ year & 64 & 3.00 & 1.18 & 283 & 10 \\
\hline 10 & religious/secular & $4^{\text {th }}$ year & 76 & 2.68 & 1.18 & 2.83 & 1.19 \\
\hline & & $1^{\text {st }}$ year & 64 & 3.11 & 1.09 & 00 & 14 \\
\hline 11 & empathetic/Self centered & $4^{\text {th }}$ year & 76 & 2.88 & 1.19 & 2.99 & 1.14 \\
\hline & & $1^{\text {st }}$ year & 64 & 3.61 & 1.20 & & \\
\hline 12 & works for peace/indifferent & $4^{\text {th }}$ year & 76 & 3.51 & 1.26 & 3.56 & 1.23 \\
\hline & & $1^{\text {st }}$ year & 64 & 3.79 & 0.55 & & \\
\hline & scale as a whole & $4^{\text {th }}$ year & 76 & 3.73 & 0.56 & 3.76 & 0.55 \\
\hline
\end{tabular}

It is noticed from Table 1 that participants demonstrated a balanced image of the scientists in a number of characteristics. These characteristics are intelligence, creativity, hard worker, responsibility, open-mindedness, caution, humane characteristics, and working for peace. The means of these characteristics range from 3.56 to 4.56 . 
However, students found difficulty in deciding on some characteristics that scientists have such as being religious, empathetic, interesting, and appreciative of beauty. The means in these traits were from 2.83 to 3.09. It also noticed from Table 1 are slight differences between $1^{\text {st }}$ and $4^{\text {th }}$ year students with regard to all the characteristics except headworker. In this area $4^{\text {th }}$ year students' mean results were higher than those of the $1^{\text {st }}$ year students. The calculations showed statistical differences in favor the $4^{\text {th }}$ year students.

Second: drawings of scientists were analyzed according to many indicators such as gender, age, physical appearance, scientific knowledge, and work location. Percentages, Frequencies, and Means were calculated as well as standard deviations. The following table shows the percentage, Frequencies and means for these characteristics that were demonstrated in the drawings of scientists.

Table 2

Percentages, Frequencies, and Means of Participants' Drawing of Scientists

\begin{tabular}{|c|c|c|c|c|c|c|c|}
\hline Indicators & Drawing & Frequencies & Percentage & $\begin{array}{l}1^{\text {st }} \text { year } \\
\text { mean }\end{array}$ & $\begin{array}{l}1^{\text {st }} \text { year } \\
\text { std. dev. }\end{array}$ & $\begin{array}{l}4^{\text {th }} \text { year } \\
\text { mean }\end{array}$ & $\begin{array}{l}4^{\text {th }} \text { year } \\
\text { std. dev. }\end{array}$ \\
\hline gender & male & 130 & $93 \%$ & 0.92 & 0.27 & 0.93 & 0.25 \\
\hline age & over 40 & 116 & $83 \%$ & 1.80 & 0.41 & 1.86 & 0.35 \\
\hline \multirow{4}{*}{$\begin{array}{l}\text { physical } \\
\text { appearance }\end{array}$} & coat & 63 & $45 \%$ & 0.38 & 0.49 & 0.51 & 0.50 \\
\hline & glasses & 56 & $40 \%$ & 0.28 & 0.45 & 0.50 & 0.50 \\
\hline & beard & 50 & $36 \%$ & 0.39 & 0.49 & 0.33 & 0.47 \\
\hline & hair & 112 & $80 \%$ & 0.80 & 0.41 & 0.80 & 0.40 \\
\hline \multirow{3}{*}{$\begin{array}{l}\text { scientific } \\
\text { knowledge }\end{array}$} & $\begin{array}{l}\text { knowledge } \\
\text { codes }\end{array}$ & 57 & $41 \%$ & 0.47 & 0.50 & 0.36 & 0.48 \\
\hline & $\begin{array}{l}\text { search } \\
\text { codes }\end{array}$ & 72 & $51 \%$ & 0.47 & 0.50 & 0.55 & 0.50 \\
\hline & terms & 18 & $13 \%$ & 0.14 & 0.35 & 0.11 & 0.32 \\
\hline \multirow[b]{2}{*}{ work place } & lab & 78 & $56 \%$ & 0.47 & 0.50 & 0.63 & 0.49 \\
\hline & $\begin{array}{l}\text { office/lectur } \\
\text { e hall/lab }\end{array}$ & 108 & $77 \%$ & 0.77 & 0.43 & 0.78 & 0.42 \\
\hline
\end{tabular}

It is noticed from Table (2) that there is a stereotypical image of the scientist held by participants in some indicators, where $93 \%$ of the students' drawings had a picture of a male scientist, and $83 \%$ of the sample pointed out that he was over 40 . A large percent (77\%) drew the scientist in a closed area and often inside a lab, $80 \%$ drew the scientist with unkempt hair, and $51 \%$ included lab equipment. It is also noticed in Table 2 that less than $50 \%$ of the drawings drew the scientist with a lab coat, with a beard or glasses, or with books in his lab. It's also noticeable from the table 2 that the image of the scientist was more often standard or stereotypical by the $4^{\text {th }}$ year students in the following indicators: age, lab coat, glasses, and included in their drawing search codes and work inside the lab. T-test was conducted and the results showed statistical differences in the following indicators: wearing glasses and working in a lab at a level of $a=0.05$ where the $4^{\text {th }}$ year students showed a more stereotypical image of scientist.

To answer the second question "What are the substantial sources that contribute to shaping the image of prospective teachers in the field of child education and classroom 
teacher about scientists?" the participants were asked to choose three sources that they count on to a large extent to get information that contributes to forming their images of scientists. Frequencies and the percentages of the participants' answers to the sources they relied on were included in the questionnaire. Table 3 shows these sources arranged according to frequencies and percentages in a descending order.

Table 3

Frequencies, Percentages of Participants' Answers to Substantial Sources that Contribute to Shaping Their Image about Scientists

\begin{tabular}{clll}
\hline Number & \multicolumn{1}{c}{ Source } & Frequencies & Percentage \\
\hline 1 & Internet & 61 & $44 \%$ \\
2 & Scientists' biographies & 59 & $42 \%$ \\
3 & School books & 54 & $39 \%$ \\
4 & Teachers \& university instructors & 41 & $29 \%$ \\
5 & Films & 39 & $28 \%$ \\
6 & Cartoons & 30 & $21 \%$ \\
7 & TV series & 29 & $21 \%$ \\
8 & Animated films & 26 & $19 \%$ \\
9 & Science magazines & 21 & $15 \%$ \\
10 & Parents & 20 & $14 \%$ \\
11 & Science museums & 8 & $6 \%$ \\
12 & Other sources & 9 & $6 \%$ \\
\hline
\end{tabular}

Table 3 shows frequencies and percentages of the substantial sources that students rely on to form an image of scientists. It is noticed the most common sources that students rely on are the Internet (44\%), followed by reading novels about scientists $(42 \%)$, academic texts (39\%), and teachers $(29 \%)$. Sources that students rely on to a lesser degree were various media sources, whether films, TV series, cartoon, animated pictures, or magazines, while scientific museums were the least used source $(6 \%)$.

To answer the third question "How much do students know about scientists in Jordan?"

Students were asked about whether there were scientists in Jordan and if so to name one Jordanian scientist. Frequencies and percentage of participants' answers were calculated and the following table shows these results.

Table 4

Frequencies and Percentage of Participants' Answers Regarding the Presence of Scientists in Jordan

\begin{tabular}{llll}
\hline presence of scientists in Jordan & Yes & No & Not sure \\
\hline Number & 32 & 92 & 16 \\
Percentage & $22.9 \%$ & $65.7 \%$ & $11.4 \%$ \\
\hline
\end{tabular}

It is noticed that students have a limited knowledge of scientists in Jordan as only $22.9 \%$ of the participants indicated the presence of such scientists, $65 \%$ of the participants indicated the absence of scientists and $11.4 \%$ were not sure. When they were asked to write the name of a scientist in Jordan, a significant number of the prospective teachers who answered yes to the question mentioned names of scholars in Islamic religion that 
whose names were mentioned in the media. Only a small percentage of the participants gave correct names of Jordanian scientists.

To answer the fourth question" Who are the most influential scientists around the world from their point of view?" prospective teachers mentioned a number of well-known scientists. The responses of the Participants were analyzed; the names of the scientists and the frequencies were listed. Table 5 shows the names of those scientists and the Frequencies according the participants' answers.

Table 5

Frequencies of Participants' Answers to Names of World Scientists

\begin{tabular}{clll}
\hline Number & Name of scientist & Frequencies & Percentage \\
\hline 1 & Einstein & 29 & $21 \%$ \\
2 & Newton & 27 & $19 \%$ \\
3 & Edison & 15 & $11 \%$ \\
4 & Avicenna & 9 & $6 \%$ \\
5 & Aristotle & 4 & $3 \%$ \\
6 & Al Khawrezmi & 3 & $2 \%$ \\
7 & Nobel & 2 & $2 \%$ \\
8 & Fleming & 2 & $2 \%$ \\
9 & Graham Bell & 2 & $2 \%$ \\
10 & Mendel & 2 & $2 \%$ \\
11 & Ibn Al Haytham & 2 & $2 \%$ \\
\hline
\end{tabular}

It is noticed from Table 5 that the names of scientists that have been repeated were Einstein, Newton, Edison, Avicenna (IbnSina), and Aristotle. When analyzing the responses of teachers to identify the reasons that led them to choose these scientists, the results showed that students' choices were based on the following reasons arranged in a descending order: discovery of laws and theories, contributions to medicine, new inventions, cognitive skills (like the ability to carry out work diligently, talented, persistent), discoveries of cures for diseases, and winning the Nobel Prize.

\section{DISCUSSION}

It is apparent from the results that student teachers who participated in the study showed a balanced image of scientists, for they indicated that scientists are distinguished by high intelligence, hard work, responsibility, and open-mindedness. However, they had difficulty deciding or knowing the extent to which a scientist had several other characteristics such as religiosity, empathy, and being interesting to others, as well as the ability to appreciate beauty. It can be said that prospective teacher showed a generally positive image of scientists' cognitive aspects while to a certain extent they expressed a negative image regarding their affective aspects. This was the same with both $1^{\text {st }}$ and $4^{\text {th }}$ year students. Many international studies have shown similar results in which scientists have many positive characteristics such as creativity, openness, objectivity, and precision (Abu-Athera, 2013; McCarthy, 2015; Huang et al., 2014; and Beardslee \& O'Dowd, 1961), or not exhibiting some characteristics like religiosity, empathy, or aesthetic appreciation (AğgülYalçın, 2012; Song and Kim, 1999). 
The results of the study also demonstrated that prospective teachers, regardless of their academic level, often have a stereotypical image. However, this image was less typical than ones revealed in previous studies such as those by Hatzinikita (2007) and Ucar (2012). A significant percentage of student teachers considered the following indicators: "a scientist is a male, has untidy hair, research devices, and works inside a lab or closed area such as a study hall or an office", as characteristics of scientists. Also, the results of the current study differ from other studies as they show an increase or decrease in the percentage of the scores of participants with regard to a number of indicators. Some previous studies showed that the most common indicators in the drawings by prospective teacher was that scientists were male, wore lab coats, glasses, and displayed research terms and devices while the results of this study showed that the most common indicators were that the scientist is a male, has untidy hair, works in a lab, and possesses research devices.

The study also determined that the images of $4^{\text {th }}$ year students were more stereotypical than those of the $1^{\text {st }}$ year students, especially those indicators related to age, lab coat, glasses, and work place. With regard to the $4^{\text {th }}$ year students the differences had a statistically significant at the level of $\mathrm{a}=0.05$ with the following indicators: working in a lab and wearing glasses. These results were interesting, especially since after a year those $4^{\text {th }}$ year students might work as teachers at the KG level or at the first three grades and therefore they could have a negative influence on students' perceptions of scientists.

The presence of this stereotypical image held by $1^{\text {st }}$ or $4^{\text {th }}$ year students can be attributed to methods used in teaching science, whether in schools or at the university level, as well as to academic text books, but this image can also be due to outside influences. It can be noted that books assigned to teacher training programs at the university do not give enough attention to the characteristics of scientists. Therefore, the courses and teaching strategies that students experience in teacher training programs do not contribute to changing the stereotypical image of scientists. This is demonstrated especially in the results of many studies that conveyed the perception of scientists and the attitudes of students toward science that are influenced by the way science is taught in teacher training programs (Mbajiorgu \& Iloputaife, 2001). Traditional science teaching methods can lead to the formation of stereotypical images of scientists. On the other hand, using constructivist methods in teaching science and offering practical scientific activities may contribute to improving scientists' images in the minds of prospective teacher. It seems that teacher training programs do not pay enough attention to learning based on inquiry or offer constructive scientific activities and extracurricular events like field trips. Such approaches involve students as active participants; reflect positively on the image that they hold about science and scientists, and offer opportunities for students to learn about successful male and female scientists that work in or out the lab.

Therefore, it is important that teacher training programs should work on images that prospective teachers have of scientists because the presence of stereotypical images of scientists formed by teachers of KG or elementary levels may convey a distorted image, whether consciously or unconsciously (Hatdimikita, 2007; Toğrol, 2013). The teacher 
who believes that scientists are older or middle-aged individuals with untidy hair, wear glasses, and work in a lab may prevent students from perceiving themselves as scientists in the future.

The students' image of a typical scientist may be attributed to academic books they have studied at school or university levels. Results of many local Arab and international studies showed that science books do not present a positive picture of scientists and do not reveal the personal characteristics of a scientist but focus on activities that the scientist performs in the lab or on their ethical values. This picture does not coincide with the contemporary image of science and scientists (Arar 2000). In addition, some of the school books in the Arab world give an image of scientists as being of western origin who work alone in the lab (Yacoubian et al., 2017). Moreover, some international studies reveal that images of scientists in school books or supporting texts lack balance regarding three indicators: presenting the scientist as white, male and old age (Rawson \& McCool 2014; Farland-Smith et al., 2017).

The results also showed that most of the prospective teachers' sources that are relied on to form an image of scientists are, in order, the Internet, science fiction novels, school books, teachers, university instructors, and films. Many results showed the importance of these sources in shaping the conception that high school and university students hold, but they varied in their importance of these sources (Turkmen, 2015; McCarthy,2015; AğgülYalçın, 2012; Abu-Saidi et al., 2015). There is no doubt that reading about scientists from sources other than assigned school texts increases knowledge about scientists and what they do, all of which reflects positively or negatively on the image of scientists held by students or pre-service teachers. To help teachers form a positive image of scientists, authors of science texts should include a number of suitable references such as books, magazines, web sites, TV programs, as well as information about the contributions of scientists in developing scientific knowledge and their significant efforts to make new discoveries that impact the quality of life and well-being of humanity.

As for students in Jordan, the image of scientists can be attributed, to a large extent, to the Internet because of the ease, speed and quantity of information received through it compared to other sources. The results also showed that prospective teacher depend on science fiction novels and school texts in forming images of scientists. On the other hand, science museums were the least sources that teachers relied on in shaping images of scientists. That might be because in Jordan there is only one science museum for children, though it includes a large number of models of various scientific topics and organizes many scientific activities.

Results of this study also showed that a large percentage of the participants (65.7\%) believe that there are no scientists in Jordan. They only mention names of scholars who specialize in Islamic sciences and who appear in various local and social media. This is likely because local media do not focus on Jordanian scientists and their contribution in the scientific fields. They also do not host such scientists as guests of their various programs and do not shed a light on the nature of their work and their accomplishments, all of which reflect negatively on the images formed of scientists and leads to incorrect 
or distorted image. Participants indicated a number of international scientists of which the most common were Einstein, Edison, and Ibni Sina. This agrees with the results that some studies in Turkey (AğgülYalçın, 2012; Bayri et al., 2016). This indicates that in diverse cultures there are similarities in the the perceptions of students or teachers about the most influential scientists in the world.

\section{CONCLUSION AND RECOMMENDATION}

The findings of the study revealed that participants had a balanced image of scientists, offering a positive perception of scientists with regard to cognitive aspects like and a rather negative perception in emotional aspects. Results also showed that participants had stereotypical image of scientists. Their perception of a scientist is an elderly male with unkempt hair, scruffy looking, and working in a lab surrounded by lab instruments. The results also showed that $65.7 \%$ of participants indicated that there are no scientists in Jordan and that the most famous international scientists were Einstein, Newton, Edison and Ibn Sina. Finding showed that the substantial sources of their images were the following: Internet, science stories, academic texts, and teachers. To help students and teachers form a positive image of scientists, it is necessary that the Ministry of Education and universities pay attention to the image of scientists in texts and school curricula. Biographies of scientists which can contribute to changing the stereotypical image that students hold of scientists should be included. In order to have a more positive view of scientists, teachers' images of scientists should be identified and they should be trained to modify them. Also, the science content on the Arabic Internet science sites should be enriched with scientists' stories and their practices. It necessary to enrich science and teaching methods courses in teacher training programs in activities that help prospective teacher to form positive images of scientists, provide them with opportunities to meet with male and female scientists by inviting them to talk about their lives, also conduct similar studies on university students of other specializations, encourage curriculum developers to promote the value of professions that are related to science and give a positive image of scientists in school texts.

\section{REFERENCES}

Abu-Athera, S. M (2013., Pre-service science teachers' perceptions of the nature of science. International Interdisciplinary Journal of Education, 2(4), 346-363.

Alzaanien, J. (2015). The mental image of science and scientists in the students of the basic stage and their relation to some variables in Gaza governorates. Arab Journal of Sciences \& Research Publishing, 1(3), 76-93.

Arar, S. (2000). The image of science in school books $\left(7^{\text {th }}, 8^{\text {th }}, 9^{\text {th }}, 10\right.$ grades $)$ in Jordan and to what extent does it match the contemporary view of science (Unpublished master thesis). University of Jordan, Jordan.

Akcy, B. (2011). Turkish elementary and secondary students' views about science and scientist. Asia-Pacific Forum on Science Learning and Teaching. 12(1), 1-11.

Ağgül Yalçın, F. (2012). Investigation of prospective teachers' image of scientist with respect to some variables. Ilkogretim Online, 11(3), 611-628. 
Ambusaidi, A., Al-Muqeemi, F., \& Al-Salmi, M. (2015). Investigation into Omani secondary school students' perceptions of scientists and their work. International Journal of Instruction, 8(1), 173-188. doi: 10.12973/iji.2015.8113a.

Bayri, N., Koksal, M. S., \& Ertekin, P. (2016). Investigating gifted middle school students' images about scientists: A cultural similarity perspective. Science Education International, 27(1), 136-150.

Beardslee, D. C., \& O'Dowd, D. D. (1961). The college-student image of the scientist. American Association for the Advancement of Science, 133(3457), 997-1001.

Chambers, D. W. (1983). Stereotypic images of the scientist: The draw-a-scientist test. Science Education, 67(2), 255-265. doi: 10.1002/sce.3730670213.

Christidou, V. (2011). Interest, attitudes and images related to science: Combining students' voices with the voices of school science, teachers, and popular science. International Journal of Environmental and Science Education, 6(2), 141-159.

Demirbas, M. (2009). The relationships between the scientist perception and scientific attitudes of science teacher candidates in Turkey: A case study. Scientific Research and Essays, 4(6), 565-576.

Dikmenli, M. (2010). Undergraduate biology students' representations of science and the scientist. College Student Journal, 44(2), 579-588.

Farland-Smith, D., Finson, K. D., \&Arquette, C. M. (2017). How picture books on the national science teacher's association recommend list portray scientists. School Science and Mathematics, 117(6), 250-258. doi: 10.1111/ssm.12231.

Finson, K. D. (2002). Drawing a scientist: What we do and do not know after fifty years of drawings. School science and mathematics, 102(7), 335-345. doi: 10.1111/j.19498594.2002.tb18217.x.

Fung, Y. Y. (2002). A comparative study of primary and secondary school students' images of scientists. Research in Science \& Technological Education, 20 (2), 199-213. doi: 10.1080/0263514022000030453.

Huang, F., Huang, Y., \& Wei, Z. M. C. (2014). A study of Chinese college students' images of the scientist. International Journal of Contemporary Educational Research, 1(2), 61-66.

Hatzinikita, V. (2007). Images of the scientist held by educators in Greece. International Journal of Learning, 14(7), 145-154.

Kaya, O. N., Doğan, A., \& Öcal, E. (2008). Turkish elementary school students' images of scientists. Eurasian Journal of Educational Research (EJER), 32, 83-100.

Karacam, S. (2016). Scientist-image stereotypes: The relationships among their indicators. Educational Sciences: Theory and Practice, 16(3), 1027-1049. doi: 10.12738/estp.2016.3.0005. 
Lucas, A. M. (1983). Scientific literacy and informal learning. Studies in Science Education, 10(1), 1-36. doi: 10.1080/03057268308559903.

McCarthy, D. (2015). Teacher candidates' perceptions of scientists: Images and attributes. Educational Review, 67(4), 389-413. doi: 10.1080/00131911.2014.974510.

Milford, T. M., \& Tippett, C. D. (2013). Pre-service teachers' images of scientists: Do prior science experiences make a difference? Journal of Science Teacher Education, 24(4), 745-762. doi: 10.1007/s10972-012-9304-1.

Mbajiorgu, N. M., \& Iloputaife, E. C. (2001). Combating stereotypes of the scientist among pre-service science teachers in Nigeria. Research in Science \& Technological Education, 19(1), 55-67. doi: 10.1080/02635140120046222.

Mead, M., \& Metraux, R. (1957). Image of the scientist among high-school students. Science, 126 (3270), 384-390. doi: 10.1126/science.126.3270.384.

Medina-Jerez, W., Middleton, K. V., \& Orihuela-Rabaza, W. (2010). Using the DAST$\mathrm{C}$ to explore Colombian and Bolivian students' images of scientists. International Journal of Science and Mathematics Education, 9(3), 657-690. doi: 10.1007/s10763010-9218-3.

Newton, L. D., \& Newton, D. P. (1998). Primary children's conceptions of science and the scientist: Is the impact of a national curriculum breaking down the stereotype? International Journal of Science Education,20(9), 1137-1149. doi: 10.1080/0950069980200909.

Ozel, M. (2012). Children's images of scientists: Does grade level make a difference? Educational Sciences: Theory and Practice, 12(4), 3187-3198.

Pion, G. M., \&Lipsey, M. W. (1981). Public attitudes toward science and technology: What have the surveys told us? American Association for Public Opinion Research, 45(3), 303-316.

Rawson, C. H., \& McCool, M. A. (2014). Just like all the other humans? Analyzing images of scientists in children's trade books. School Science and Mathematics, 114(1), 10-18. doi: 10.1111/ssm.12046.

Rosenthal, D. B. (1993). Images of scientists: A comparison of biology and liberal studies majors. School Science and Mathematics, 93(4), 212-216. doi: 10.1111/j.19498594.1993.tb12227.x .

Sharkawy, A. (2012). Exploring the potential of using stories about diverse scientists and reflective activities to enrich primary students' images of scientists and scientific work. Cultural Studies of Science Education, 7(2), 307-340. doi: 10.1007/s11422-0129386-2.

She, H. C. (1998). Gender and grade level differences in Taiwan students' stereotypes of science and scientists. Research in Science \& Technological Education, 16(2), 125135. doi: 10.1080/0263514980160203. 
Schibeci, R. (2006). Student images of scientists: What are they? Do They Matter, 52(2), 12-17.

Song, J \& Kim, K (1999). How Korean students see scientists: The Images of the Scientist. International Journal of Science Education, 21(9), 957-977. doi: $10.1080 / 095006999290255$.

Toğrol, A. Y. (2013). Turkish students' images of scientists. Journal of Baltic Science Education, 12(3), 289-298.

Türkmen, H. (2015, June). Still persistent global problem of scientists' image. AsiaPacific Forum on Science Learning \& Teaching, 16(1), 377-397.

Ucar, S. (2012). How do pre-service science teachers' views on science, scientists, and science teaching change over time in a science teacher training program? Journal of Science Education and Technology, 21(2), 255-266. doi: 10.1007/s10956-011-9311-6.

Ünver, A. O. (2010). Perceptions of scientists: A comparative study of fifth graders and fourth year student teachers. Necatibey Faculty of Education Electronic Journal of Science \& Mathematics Education, 4(1), 11-28.

Yacoubian, H. A., Al-Khatib, L., \& Mardirossian, T. (2017). Analysis of the image of scientists portrayed in the Lebanese national science textbooks. Science \& Education, 26(5), 513-528. doi: 10.1007/s11191-017-9908-0 .

Azhar M. (2007) Level of professionalism among Islamic education trainees in practical teaching (Unpublished master thesis). Universiti Teknologi Malaysia, Malaysia. 